\title{
The Hungarian media system under political pressure
}

\author{
Interview with Prof. Péter Bajomi-Lázár \\ BUDAPEST BUSINESS SCHOOL, HUNGARY
}

DOI: 10.19195/1899-5101.12.2(23).9

Professor Péter Bajomi-Lázár was interviewed by Agnieszka Stępińska in May 2018. ${ }^{1}$

Now, it is eight years since the new media law was introduced by Victor Orbán's government. Can you say - from that time perspective - which particular changes of the law affected the media system and journalists the most? Or maybe it is the practice of the party in power that influenced the media the most?

I think both the law and its implementation were meant to completely retransform Hungary's media system. The new law created a new media authority with new members. All members of the Media Council were delegated by the Fidesz party, while its first chair was nominated by Prime Minister Viktor Orbán himself. (Now the chair is delegated by the President of the Republic who also happens to be a former Fidesz member.) In other words, a new nomenklatura system was created to take over decision-making positions in order to control the redistribution of media resources. Of course, the members are bound to be independent by media law, but can a one-party body ensure the pluralism of voices? Certainly not.

The media landscape is totally different now compared to what it was 10 years ago. Before the electoral victory of Fidesz and the Christian Democrats, Hungary was ranked 23rd on the Reporters Without Borders' global list of media freedom, while in 2017 it was ranked 71st, which means that it dropped nearly 50 places in eight years. Hungary used to be a "free press" country according to Freedom House, but now it is listed among the "partly free" countries, along with Bulgaria, Romania, and countries of the Western Balkans. It is probably not a mistake to describe this process as the Balkanization of the media in Hungary.

1 The work was funded by the National Science Centre, Poland, grant no. 2015/18/M/ HS5/00080. 
In the first four years of Fidesz's rule (2010-2014), one could observe the colonization of the media authority, the public broadcasters and the national news agency as well as the exploitation of their resources such as radio and television frequencies and air time for party purposes. In the second term (2014-2018), many private outlets were captured, too, including print newspapers, radio stations, television channels, and online news sites. By the last legislative elections that were held in April 2018, Fidesz had established a near-hegemony of its position in the media, especially in the rural areas of the country. Nearly all the regional newspapers are now controlled by Lőrinc Mészáros, a former mayor in Orbán’s native village and a childhood friend of the Prime Minister. TV2, the second nationwide commercial channel, is now owned by Andrew G. Vajna, once a Hollywood producer known for movies like Rambo, Rambo II and Rambo III, and now a government commissioner in charge of the film industry. Many online news sites are now run by the Modern Media Group, owned by Árpád Habony, unofficial communication advisor to the Prime Minister. Links between the media oligarchs and the government are not as informal in Hungary as they are in many other countries in Central/Eastern Europe.

If you live in the countryside, you can read the regional newspaper owned by Mészáros, you can listen to the local commercial radio station (most likely Radio 1, also owned by Andrew G. Vajna) which airs music and the news bulletins provided by the national news agency free of charge every hour, displaying a marked pro-government bias. You can watch the seven television channels and listen to the seven radio stations of the public broadcaster, and perhaps listen to a Catholic and Protestant radio station, too. The only left-wing daily newspaper called Népszava (The Voice of the People) may also be available if you are a subscriber, but its independence is now a matter of debate. In $2017,56 \%$ of its total advertising revenues came from state advertising. There is one exception, though, that undermines this rule: The evening news bulletins and the late-night current affairs programs of the nationwide commercial television channel RTL Klub are highly critical of the government and available throughout the country.

Frequency allocation is managed by the media authority. It has redistributed radio frequencies, granting many of them to Radio 1 and to Catholic and Protestant radio networks, while it failed to renew the regional licenses of Club Radio, the only oppositional voice that is now available in the capital city Budapest only.

Another media resource that has been redistributed is state advertising. Before 2010 , state advertising amounted to around 3\% of the total advertising market. Now, it is estimated at $27 \%$, while the European average is $7 \%$. This is how the government is funding pro-government media content such as anti-Soros and anti-immigration campaigns.

Public radio stations and television channels are now indisputably agents of progovernment propaganda. Opinion polls show the even Fidesz voters recognize this bias in their news programs. 
After the financial and economic crisis of 2008, most foreign investors left the country, which enabled government clients to purchase their outlets, sometimes with the help of major loans provided by state-owned banks such as Eximbank, as the example of TV2 demonstrates.

Public information is another important media resource. However, access to it is a lot more limited than it used to be. The journalists of critical media outlets have repeatedly been forbidden to enter the House of Parliament and public events involving senior government officials. A number of public documents have been classified as state secrets; for example, it is unclear how the new nuclear power plant, to be constructed by the Russians, will be financed. Also, a new law binds citizens, including journalists, to pay an unspecified amount of money if they submit a request for public information. The fee may amount to millions of forints.

You can argue that there are two ideal-type media policies. A universalistic media policy means that the state remains neutral and media policy is used as a means to enhance equal access to the media for all across the political spectrum. A particularistic media policy, by contrast, means that media resources are redistributed on the basis of political loyalty, that is, to people representing the same political perspective. If you consider these two types as the two opposite ends of a spectrum, Hungary lies very close to the latter. Public media resources have been moved into private hands. Arguably, a clientelistic media system, based on the mutual exchange of "favors" between patrons and clients, has been established. Most media outlets promote particular interests, while the public interest is largely ignored.

Of course, similar cases occur across Central/Eastern Europe, but Hungary seems to be a textbook example of some of the worst practices.

What you have described so far are the changes at the macro- and the mesolevels of the media system. But there is also a micro-level that describes journalists at their work. Based on your studies and conversations with Hungarian journalists, how could you describe their mood and attitude now? Are they still fighting over media or have they already given up?

Consider what could be called the Maslow pyramid of journalism. Ethical journalism is located on the highest level of this pyramid. Then, further down the scale, there are acceptable work conditions, existential security, a functional media market and, finally, media freedom at the lowest level of this pyramid. As long as there is no media freedom and the media market is highly distorted (by excessive and favoritist state intervention), there will be existential insecurity and often very poor working conditions. Under such circumstances, most journalists cannot afford to engage in ethical journalism. 


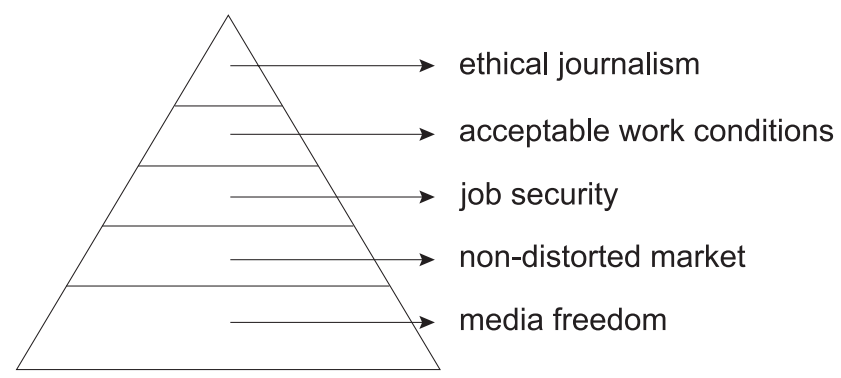

Figure 1. The Maslow pyramid of journalism

Source: Author.

Hence, despite efforts made after the political transformation in the early 1990s to adopt the Anglo-American standards of ethical journalism, this type of journalism is the exception rather than the rule to date. There are many types of journalists' misdemeanors. These include character-killing campaigns, the black-listing in newspapers of pubic intellectuals with critical political views, and the massive production of fake news. (Of course, there have always been hoaxes. But to date, fake news items are released by different media outlets simultaneously: This is a coordinated dissemination of fake news.) Moreover, journalists on all sides are highly partisan and promote black-and-white images of the real world. The journalist community is deeply divided along ideological cleavages.

I would suggest that for ethical journalism to be realized at least three conditions should be met. First, media freedom: If journalists are facing political pressures and the instrumentalization of the media for private interests, they have to serve their masters and hence cannot follow their own rules. Second, a non-distorted media market: Market distortions in this case are actually aimed at sanctioning ethical journalism and at rewarding unethical reporting. Unethical journalism has become an adaptation strategy, and even a successful business model. Third, ideological and political consensus: Society must express a clear social mandate for journalists, there must be some kind of a common idea across the board of what the job of journalists is. In Hungary, these three conditions are missing to date.

\section{When you talk about poor working conditions do you mean salaries and finan- cial security of journalists or a more general context?}

This is a more complex issue. If someone works for an independent news outlet that is struggling to survive on the media market, it is indeed a serious financial challenge. State advertising is now mainly placed in pro-governmental outlets, and even private companies think twice before placing their advertising in independent media (because it may be bad for business). Journalists of the independent media do not know how long they will last. 
At the same time, there are many freelancers among journalists. These people are not protected by collective contracts and live in permanent financial insecurity. Also, they are usually paid by the page, whose practice promotes quantity journalism as opposed to quality journalism. Further, freelance journalists are unlikely to follow the code of ethics of the editorial room, and they certainly cannot be bound to do so. Even established professional journalists have lost their jobs. After 2010, public media dismissed 570 people.

\section{What is the situation and role of the online media in Hungary? Are they an al- ternative source of information for society?}

In Hungary, internet penetration is nearing the European average with around $70 \%$ of the population having access to the web. The internet is mainly used by young, well-educated people who live in urban areas. By contrast, the rural population working in the fields or in the factories has no opportunity to use online news sources. At the same time, pro-government voices are also present online, including quality and tabloid news sites and social media. To be sure, the internet is much freer and more plural than the rest of the media. However, the government's influence has been growing there, too. Government cronies have purchased the most popular online news site Origo.hu, and now, due to its new ownership structure, the independence of Index.hu is also at risk; its journalists have recently launched a crowd-sourcing campaign.

In sum, Hungary's autocratic government does not use violence or overt censorship to control media. The main instrument of control is the re-distribution of media resources that slowly but permanently increases the pressures that journalists and newsrooms are exposed to.

Péter Bajomi-Lázár (1969) is a Professor of Mass Communication at the Budapest Business School. He worked as the editor of the Hungarian media studies quarterly The Media Researcher (Médiakutató) between 2000 and 2016 and as a Senior Research Fellow with "Media and Democracy in Central and Eastern Europe," a European Research Council project based at Oxford University between 2009 and 2013. In 2002, he was granted the Hungarian Pulitzer Memorial Award for his book on Hungary's media war (A magyarországi médiaháború, 2001). His latest monograph is Party Colonisation of the Media in Central and Eastern Europe (The Central European University Press, 2014). His latest edited volume is Media in Third-Wave Democracies: Southern and Central/Eastern Europe in Comparative Perspective (L'Harmattan, 2017). 


\section{RECENT PUBLICATIONS}

Bajomi-Lázár, P. (2019). Inequality in the media and the "Maslow pyramid" of journalistic needs in Central and Eastern Europe. In J. Trappel (Ed.), Digital media inequalities: Policies against divides, distrust and discrimination (pp. 113-126). Göteborg: Nordicom.

Bajomi-Lázár, P., \& Kékesdi-Boldog, D. (2018). Zurück in die Zukunft. Das Wiedererstarken autoritärer Medienpolitik in Ungarn. Osteuropa, 3-5, 273-282.

Bajomi-Lázár, P. (2017). Particularistic and universalistic media policies: Inequalities in the media in Hungary. Javnost/The Public, 22(2), 162-172.

Bajomi-Lázár, P. (2017). Between neutrality and engagement: Political journalism in Hungary. Central European Journal of Communication, 10(1), 48-63.

Bajomi-Lázár, P. (2015). Variations in media freedom: Why do some governments in Central and Eastern Europe respect media freedom more than others? Central European Journal of Communication, 8(1), 4-21. 